\title{
Surface deformation on the west portion of the Chapala lake basin: uncertainties and facts
}

\author{
M. Hernandez-Marin ${ }^{1}$, J. Pacheco-Martinez ${ }^{1}$, J. A. Ortiz-Lozano ${ }^{1}$, G. Araiza-Garaygordobil ${ }^{1}$, and \\ A. Ramirez-Cortes ${ }^{2}$ \\ ${ }^{1}$ Departamento de Geotecnia e Hidráulica, Universidad Autónoma de Aguascalientes, Aguascalientes, Mexico \\ ${ }^{2}$ Doctorado en Ciencias de los Ámbitos Antrópicos, Universidad Autónoma de Aguascalientes, Aguascalientes, \\ México
}

Correspondence to: M. Hernandez-Marin (mhernandez@ correo.uaa.mx)

Published: 12 November 2015

\begin{abstract}
In this study we investigate different aspects of land subsidence and ground failures occurring in the west portion of Chapala lake basin. Currently, surface discontinuities seem to be associated with subsiding bowls. In an effort to understand some of the conditioning factors to surface deformation, two sounding cores from the upper sequence $(11 \mathrm{~m}$ depth) were extracted for analyzing physical and mechanical properties. The upper subsoil showed a predominant silty composition and several lenses of pumice pyroclastic sand. Despite the relative predominance of fine soil, the subsoil shows mechanical properties with low clay content, variable water content, low plasticity and variable compressibility index, amongst some others. Some of these properties seem to be influenced by the sandy pyroclastic lenses, therefore, a potential source of the ground failure could be heterogeneities in the upper soil.
\end{abstract}

\section{Introduction}

Mexico is one of the most affected countries by anthropogenic subsidence. Here, conditioning factors such as topography, hydrostratigraphy, depositional environments, and others are combined with large periods of groundwater withdrawal, resulting in surface deformation in the form of subsidence (vertical deformation), or faulting and fissuring (horizontal or combined horizontal and vertical deformation). The zone known as the Transmexican Volcanic Belt is perhaps the most affected area in the country, mostly due to the postdepositional processes resulting in fine sediments that potentially contain smectitic clays, usually derived from volcanic materials deposited in lacustrine and currently urbanized valleys such as Mexico City, Queretaro, Chapala, and others.

In this work, new findings regarding surface deformation on the west portion of the Chapala lake basin are analyzed and discussed, and previous measured land subsidence previously measured and mapped faults are recalled. Novel information includes the description and geotechnical characterization of sediments from two cores of $11 \mathrm{~m}$ from of the upper sedimentary sequence. Additionally, uncertainties regarding the factors that may condition or trigger surface deformation in this particular area are discussed.

\section{Conditions of Chapala lake basin}

The lake of Chapala and its potential flooding area is bounded by ranges. The elevation difference between the top of the mountains and the lacustrine plain is close to $500 \mathrm{~m}$. This difference is more significant along the western portion of the basin. Due to the potential for tourism on the lake shore, several urban centers around the lake have experienced significant growth in the past few decades, one of them is the community of Jocotepec on the west with close to 37700 inhabitants (INEGI, 2010). The increasing population in all communities around the lake has triggered the demand of water to satisfy agricultural and municipal needs in the last decades. Usually people from the valley prefer groundwater because is cleaner and more accessible than the water from the lake.

In the basin of Chapala lake, as most inside the Transmexican Volcanic Belt, tectonism, volcanism and sedimen- 


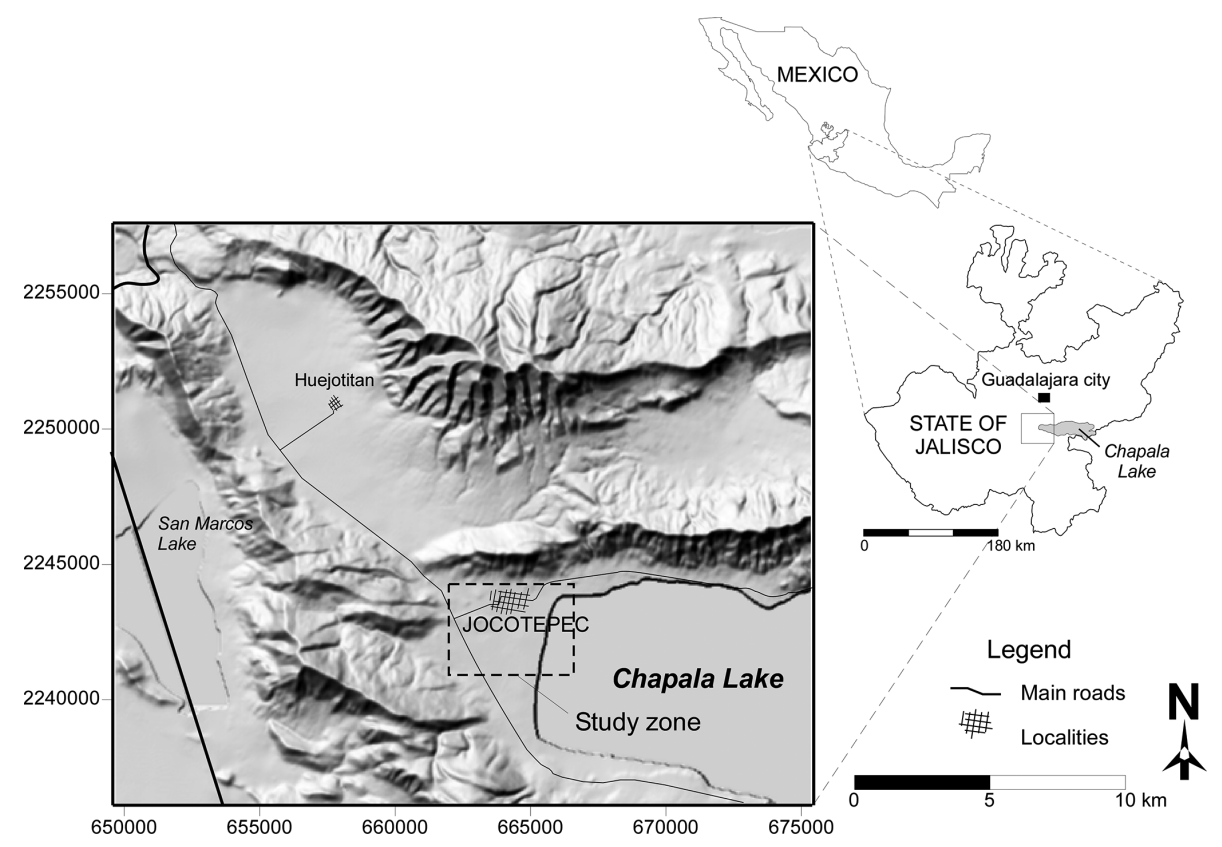

Figure 1. Location of the study area in the west part of the Chapala lake. From Hernandez-Marin et al. (2014).

tation occurred simultaneously during tertiary an quaternary ages. Regionally, this basin is seismically active with recent shallow earthquakes. This basin presents its longest side in an east-to-west direction, which is collinear to the main regional fault system. The ranges bounding the lake plain are mainly volcanic and plutonic, formed by basalts, rhyolite and pyroclastic material (Rosas-Elguera and Urrutia-Fucugauchi, 1998); and the sedimentary sequence of the plain presents alluvial, lacustrine and volcanic deposits (ash) including sands, silts and clays (Zarate-del-Valle and Simoneit, 2005). Figure 1 depicts the location and main characteristics of the study area.

Land subsidence in this part of Mexico is recent since the first reports of surface deformation are from the early 90 's, however, it was not documented until 2007 by Castillo-Aja and Valdivia-Ornelas (2007). Locally, the first cores for physically analyzing sediment samples were used to determine mineralogy of the fine sediments and the rate of sedimentation (Fernex et al., 2001). Through the soil samples from these cores it was observed that the main minerals of the clay portion are halloysite, hectorite and illite, and the sand grains are mainly composed of vitreous volcanic ash (pumice) (Fernex et al., 2001).

\section{Monitoring campaign of surface deformation}

Land subsidence and surface faulting have recently been a recurrent problem in the urban area of Jocotepec and suburbs. The problems associated to ground deformation include damage to buildings, roads and other constructions. In 2012, as part of a project to quantify subsidence, identify ground failures and determine damage to infrastructures, it was found that for a period of 8 months (April-November), a maximum deformation of $7.16 \mathrm{~cm}$ was measured with a calculated rate of $0.89 \mathrm{~cm} \mathrm{month}^{-1}$. Additionally, two zones of the surveyed area showed uplifting close to $2 \mathrm{~cm}$. Four alignments of surface faults with preferential direction SW-NE are affecting several constructions (Hernandez-Marin et al., 2014). Land subsidence, fault alignments and other characteristics are shown in Fig. 2.

\section{Sampling and analyses}

In order to determine the stratigraphy of the upper sequence $(<11 \mathrm{~m})$ inside the subsiding zone, and determine its main geotechnical properties, two cores of $11 \mathrm{~m}$ depth were sampled. Analyses included stratigraphy determination, sediment description and geotechnical testing in accordance with ASTM standards.

\subsection{Stratigraphy of the analyzed sequence}

Observations from samples in both cores indicate a predominance of green-olive fine sediments with minor layers of brown fine sediments and alternating gray-light and graydark pyroclastic sand. The thickness of the sandy layers is variable in both cores, in core 1 (northernmost) is more than $2 \mathrm{~m}$, but in the core 2 (drilled at $287 \mathrm{~m}$ to the southeast from the core 1) the thickness is close to $20 \mathrm{~cm}$ only. Figure 3 shows the observed stratigraphy with descriptions of the sediments from the sampled cores. 


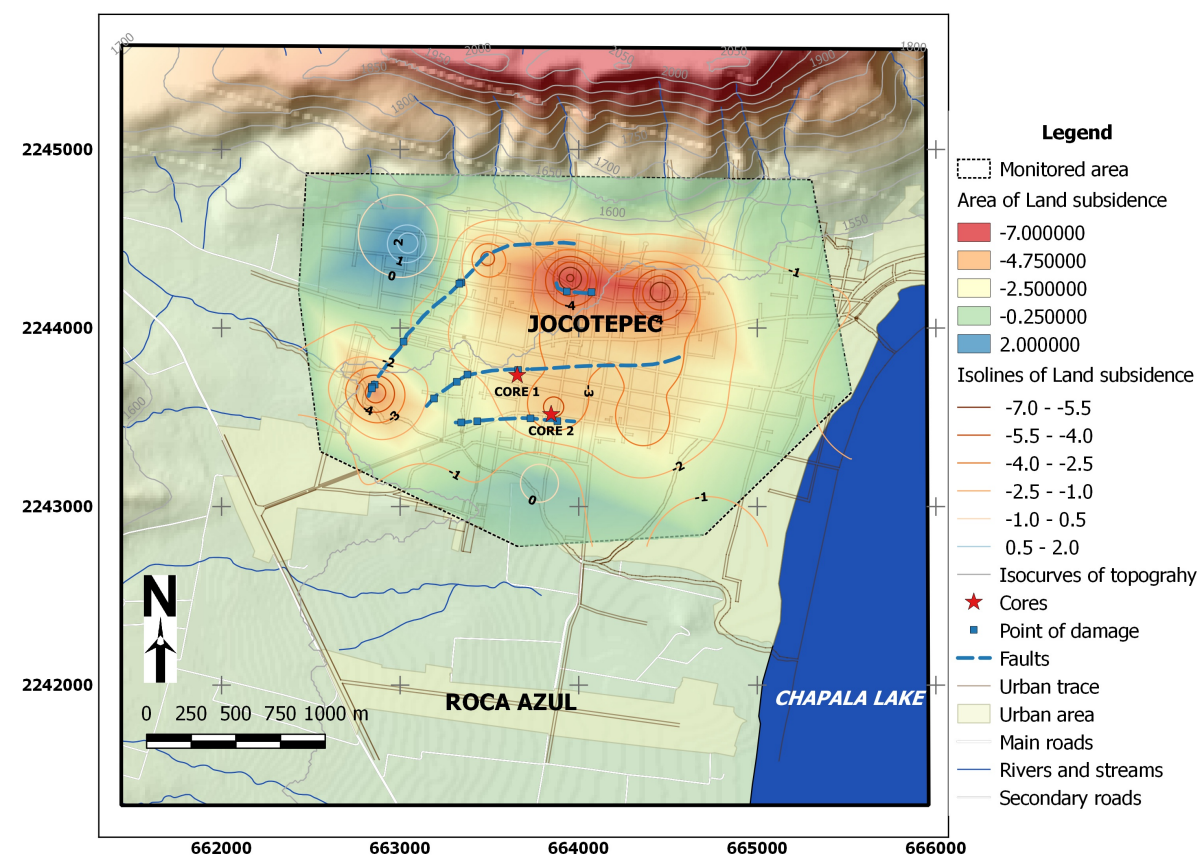

Figure 2. General characteristics of the study zone at west Chapala lake basin. Subsidence registered and fault alignments observed in 2012 are present. Also the two cores for geotechnical analysis of the subsoil are indicated. Units of area and isolines of land subsidence are in centimeters.

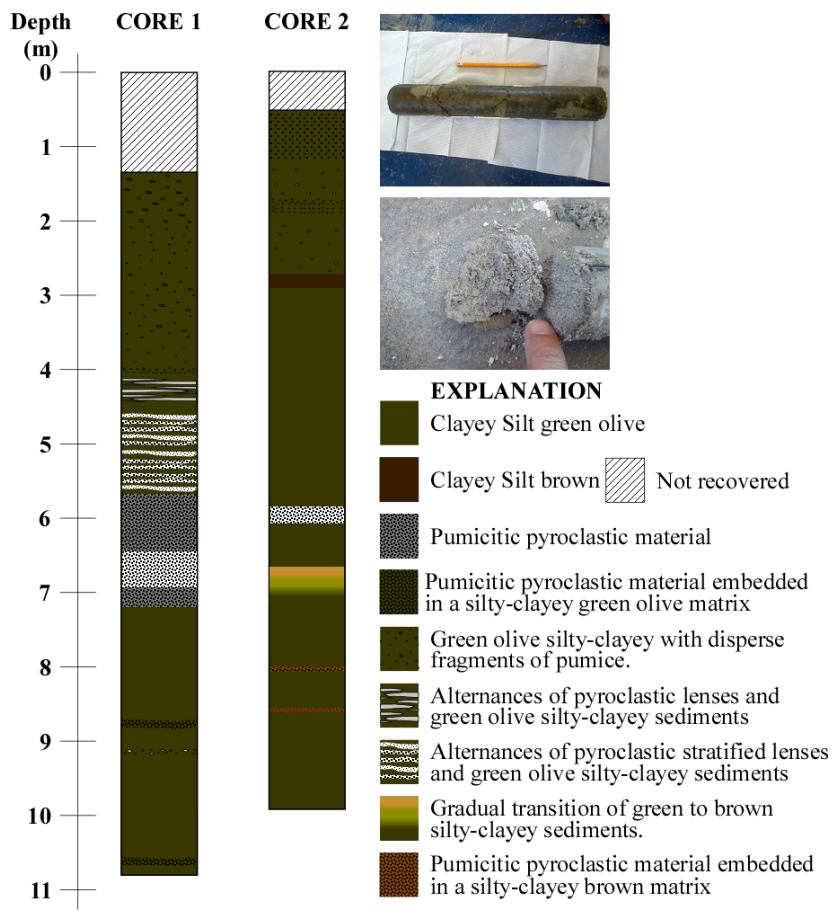

Figure 3. Described stratigraphy of both cores. Sample photographs of the predominant green-olive sediments, along with an example of a pumice sandy layer are shown.

\subsection{Grain-size, water content, consistency limits and compressibility}

Even though the sequence appears to be macroscopically dominated by fine sediments, the grain-size of sediments passing sieve \# 10 ( $\leq 2 \mathrm{~mm}$ ) using the hydrometer technique, demonstrated the presence of fine sands, particularly in core 1. As observed in Fig. 4 the clay content is very low in core 1 , in comparison with the high content found at some depths in core 2, were proportion is as high as $37 \%$ between 1 and $2 \mathrm{~m}$ (Fig. 5). Gravimetric water content is low compared with soil samples from other volcano-lacustrine basins such as Mexico City. Maximum water content is close to $215 \%$, although most of the water content measurements are no higher than $150 \%$, (in Chalco basin, adjacent to Mexico City, for instance, water content can reach $350 \%$, Hernandez-Marin, 2003). Consistency limits are low with liquid limits lower than $50 \%$. Finally, to obtain the compressibility properties, consolidation test were performed from unaltered samples. In general, compressibility index is lower than 0.2 (only one determination was close to 0.4), as shown in Figs. 4 and 5.

\section{Uncertainties and discussion}

Many questions remain unanswered regarding the process of subsidence in the locality of Jocotepec and in general in the Chapala lake basin. Some of these questions are for instance: is the groundwater depletion the unique process causing land subsidence? As demonstrated in Hernandez-Marin 

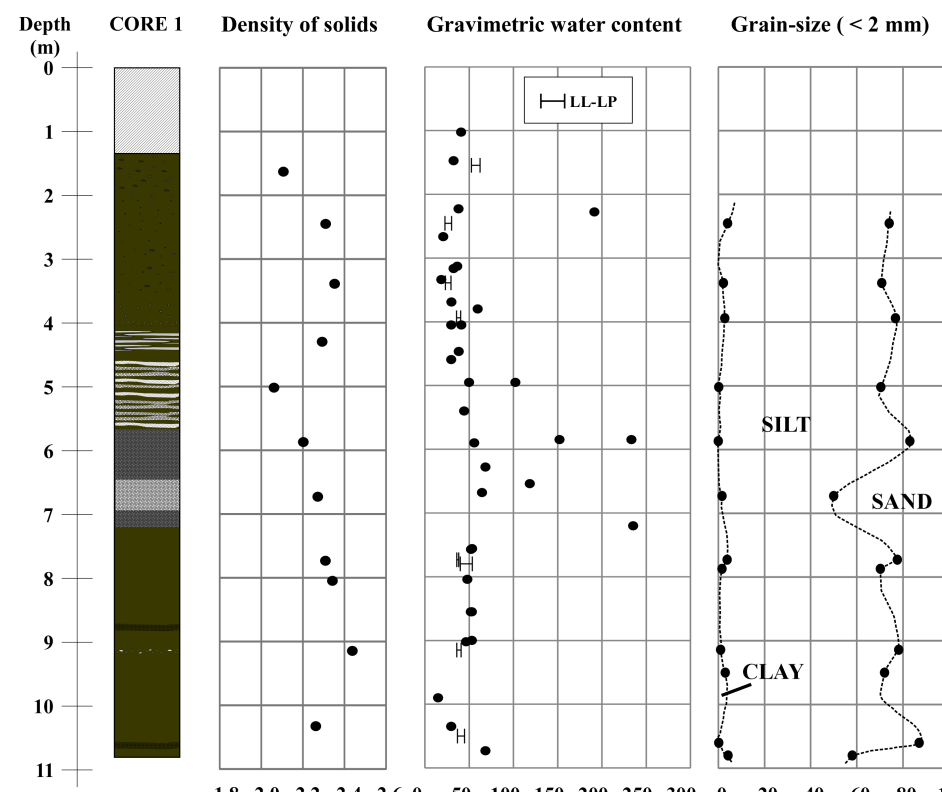

Compressibility index
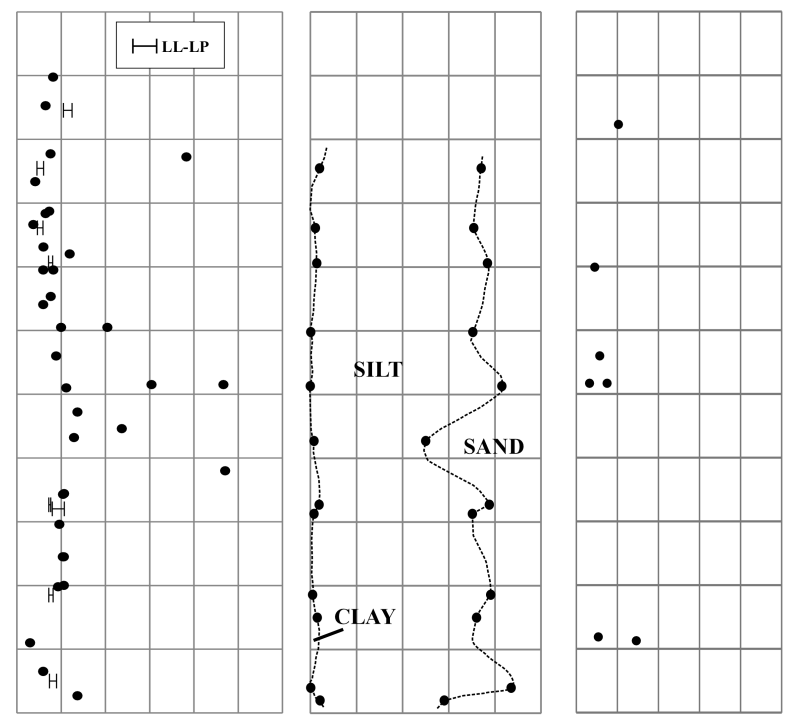

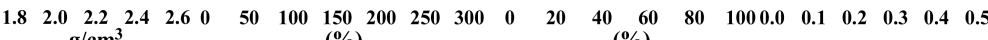
/ $\mathbf{c m}^{3}$

(\%)

(\%)

Figure 4. Core one and some of its geotechnical properties. LL-LP represents the values of liquid and plastic Atteberg limits.

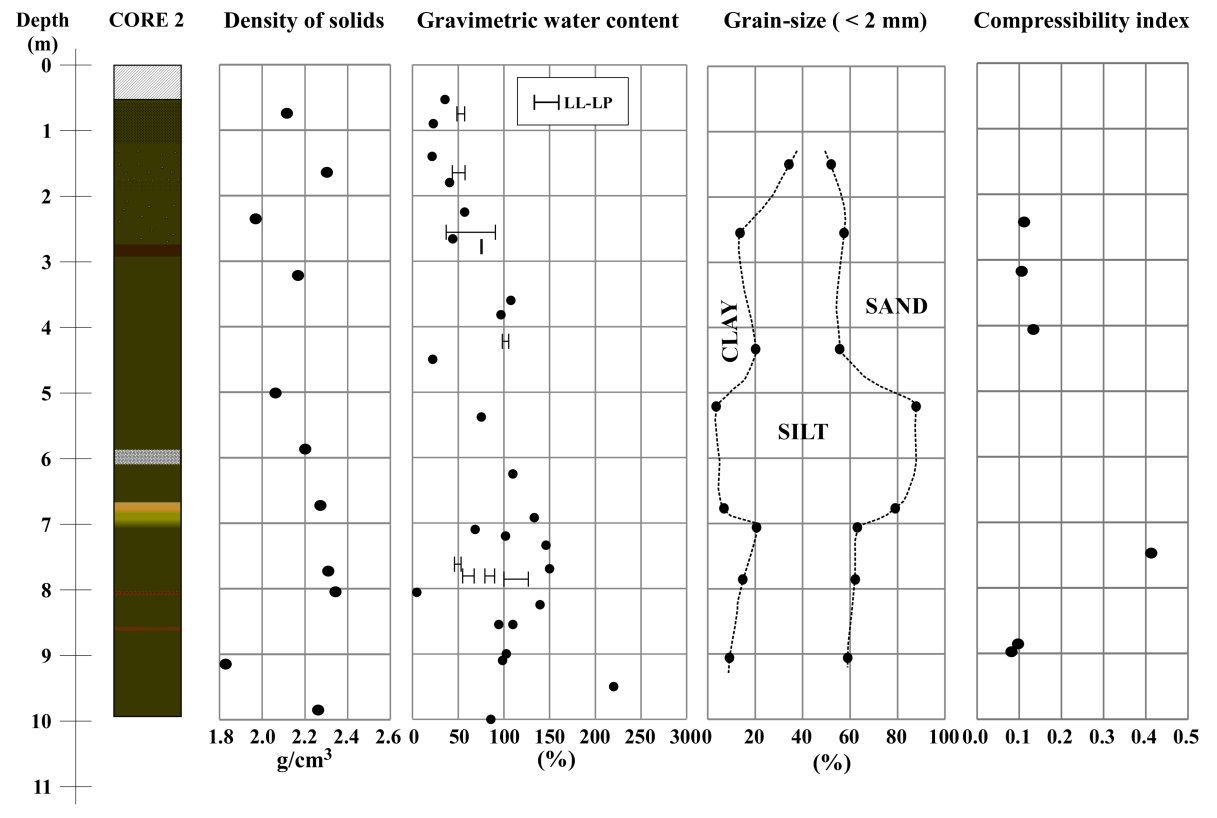

Figure 5. Core two and some of its geotechnical properties. LL-LP represents the values of liquid and plastic Atteberg limits.

et al. (2014), subsidence bowls do not coincide with groundwater cones of depression, even though some cones of depression are remarkable due to intensive pumping for irrigation at the south of the study area. Even though groundwater levels are shallow in most of the area, since as observed during drilling of cores, the groundwater table was no deeper than $2 \mathrm{~m}$. Another question is regarding the tectonic component: is this stress contributing to surface deformation? The zone is tectonically active and is regionally dominated by a triple junction rift-rift-rift (Pacheco et al., 1999). The last registered earthquake occurred in 17 May 2012, of magnitude 4.4 and the epicenter was located $6 \mathrm{~km}$ from the study zone, as reported by the National Seismological Service, indicating tectonic activity and potential stressing. Fault alignments tend to follow isolines of subsidence, as presented in Fig. 2, however that tendency is only suggestive; therefore, the real relationship between faults and subsidence is still under investigation. The origin of faults is also unknown. 
A first hypothesis is that differential subsidence due to heterogeneities in the lacustrine sequence is the possible cause. However, future work must corroborate this hypothesis.

\section{Conclusions}

New information regarding the geotechnical properties of the upper sequence of the west portion of Chapala lake basin is presented and discussed, and the previous study to quantify subsidence and delineate ground failures is revisited. Two cores for the geotechnical analysis of sediments show predominance of silt and fine sand, whereas geotechnical properties such as water content, consistency limits, and compressibility index are low compared with samples from other volcano-lacustrine basins such as Mexico basin. Differences in the stratigraphy, in particular those related to pumice layers, less compressible than silty and clayey layers, are a potential cause to differential subsidence and surface faulting.

Acknowledgements. This work was financed by the Autonomous University of Aguascalientes with the internal project: PIIC13-4N. The authors are also thankful for the reviewers comments, which improved the quality of this manuscript.

\section{References}

Castillo-Aja, M. R. and Valdivia-Ornelas, L.: Amenazas por agrietamiento en el Valle de Tesistán [Risks due to cracking in the valley of Tesistan], Universidad de Guadalajara, 2007

Fernex, F., Zarate-del-Valle, P., Ramirez-Sanchez, H., Michaud, F., Parron, C., Dalmasso, J., Barci-Funel, G., and Guzman-Arroyo, M.: Sedimentation rates in Lake Chapala (western Mexico): possible active tectonic control, Chem. Geol., 177, 213-228, 2001.
Hernandez-Marin, M.: Estudio del comportamiento hidromecánico de sedimentos vulcanolacustres durante el proceso de consolidación [Study of the hydromechanic behavior of the vulcanolacustrine sediments during the process of consolidation], Master Dissertation, National Autonomous University of Mexico, Mexico, 2003.

Hernandez-Marín, M., Pacheco-Martínez, J., Ramírez-Cortés, A., Burbey, T. J., Ortíz-Lozano, J. A., Zermeño-De-Leon, M. E., Guinzberg-Velmont, J., and Pinto-Aceves, G.: Evaluation and analysis of surface deformation in west Chapala basin, central Mexico, Environ. Earth Sci., 72, 1491-1501, 2014.

INEGI: Censo de población y vivienda [Census of population and housing], Mexico, 2010.

Pacheco, J. F., Montera-Gutierrez, C. A., Delgado, H., Singh, S. K., Valenzuela, W., Shapiro, N. M., Santoyo, M. A., Hurtado, A., Barron, R., and Gutierrez-Miguel, E.: Tectonic significance of an earthquake in the Zacoalco half-graben, Jalisco, Mexico, J. S. Am. Earth Sci., 12, 557-565, 1999.

Rosas-Elguera, J. G. and Urrutia-Fucugauchi, J.: Tectonic control of the volcano-sedimentary sequence of the Chapala graben, western Mexico, Int. Geol. Rev., 40, 350-362, 1998.

Zarate-del-Valle, P. and Simoneit, B.: La generación de petróleo hidrotermal en sedimentos del Lago Chapala y su relación con la actividad geotérmica del rift Citala en el estado de Jalisco, México [Generation of hidrotermal oil into the Chapala Lake sediments and its relationship with the geotermal activity of the Citala rift in the state of Jalisco, Mexico], Revista Mexicana de Ciencias Geológicas, 22, 358-370, 2005. 